\title{
Measurement of some Biochemical Parameters in Serum of Uterine Cancer
}

\author{
Kinda M. Bilal \\ Department of Chemistry \\ College of Education \\ University of Mosul
}

(Received 21/10/2012; Accepted 7/1/2013)

\begin{abstract}
The research includes measurement of some biochemical parameters in serum of uterine cancer patients. Serum samples were collected from (20) healthy females and (20) females with uterine cancer, their ages ranged between (35-68) years. These parameters included: lactate dehydrogenase (LDH) activity and the level of some antioxidants like vitamin $\mathrm{C}$, vitamin $\mathrm{E}$, glutathione (GSH), malondialdehyde (MDA) and peroxynitrite. Some trace elements (copper and zinc) were also tested in the present study.

In comparison with the healthy females, the uterine cancer exhibited a significant increase in the level of MDA, peroxynitrite, $\mathrm{LDH}$ and copper. They also exhibited a significant decrease in the level of vitamin $\mathrm{C}$, vitamin $\mathrm{E}$, glutathione and zinc in comparison with healthy females.
\end{abstract}

Keyword: Lactate dehydrogenase, uterine cancer, antioxidants

\section{قيلس بصن المنغيرل الكيمحيوبة في مطل المصلبك بسولن الرهم}

\section{الملغص}

تضمن البمث قيلس بعض المتغيرات الكيموحيوية في مصل المصابلت بررطلن الرهم ـ جمعت نم اذج

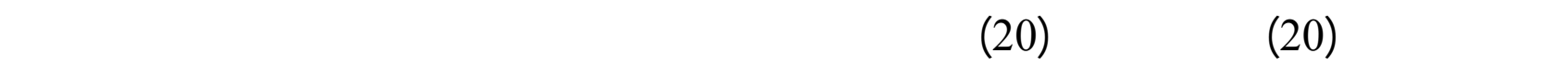

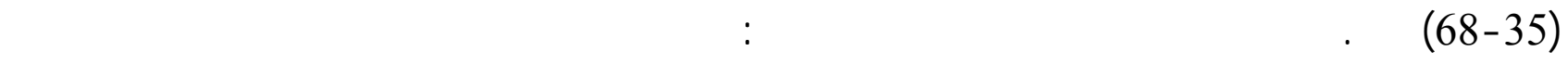
مستوى بعض مضادات الأكسة مل فيتلمن C، فيتلمن E والكلوتالثايون فضلاً على التعرف على مـ ستوى

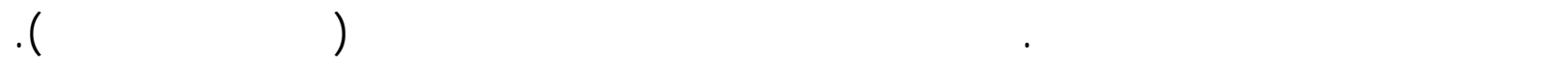

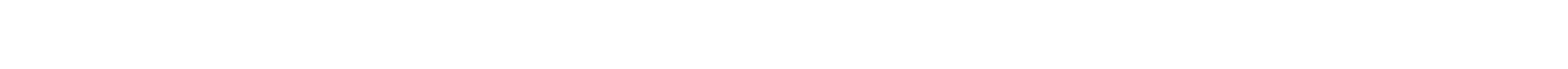

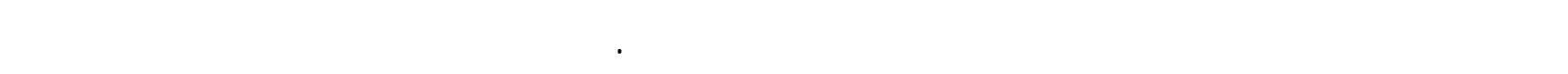

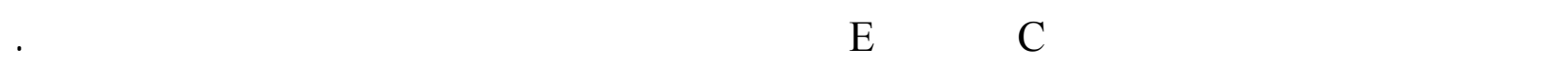

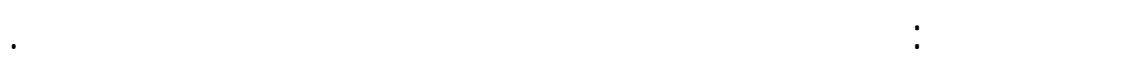




\section{INTRODUCTION}

Cancer is a complex disease, involving numerous tempospatial changes in cell physiology, which ultimately lead to malignant tumors, it is characterized by an increase in the number of abnormal cells and an invasion of adjacent tissue by these cells, followed by a spread of malignant cells to distant sites (Seyfried and Shelton, 2010; Gillham et al., 2000).

Uterine cancer is the most common gynaecological cancer, it is also called womb cancer or endometrial cancer (Buchanan et al., 2009). Nearly all cancers of the uterus start in the lining of the uterus (The endometrium), it is more common in women over 45 year than younger women. Most (over $80 \%$ ) of endometrial cancers are typical adenocarcinomas (Allen et al., 2011; Giordano et al., 2007).

The causes of the uterine cancer may be attributed to the carcinogenic chemicals, radiation and oxidative stress (Sun, 1990). Oxidative stress is defined as an imbalance between the formation of oxidant compounds and antioxidants defense mechanisms (Naidu et al., 2007). Inadequate antioxidant protection or excess production of free radicals, particularly oxygen radicals create oxidative stress, which causes cell damage and plays a fundamental role in various diseases like cancer (Naidu et al., 2007; Pejic et al., 2006).

Severe oxidative stress is not only known to cause DNA damage and mutations of tumor suppressor genes, which are initial events in carcinogenesis (Kang, 2002), but can also play an important role in the promotion of multistep carcinogenesis (Ahmed et al., 1999).

Antioxidants are the first line of defense against the free radical damage. Human cells are equipped with both enzymatic and non- enzymatic antioxidant defense mechanisms to minimize the cellular damage resulting from the interaction between the cellular constituents and the reactive oxygen species (ROS) (Mila-Kierzenkowska et al., 2004). Epidemiological evidence consistently relates low antioxidants intake or low blood levels of antioxidants with an increased cancer risk (Block, 1992).

The present study discusses the role of oxidative stress in causing uterine cancer by determining the level of: antioxidants, LDH and trace elements in females of uterine cancer compared with healthy ones.

\section{Subjects}

\section{MATERIALS AND METHODS}

The females included two groups, patient and healthy. The patient group consisted of (20) females with diagnosed uterine cancer aged (35-68) years. The samples collected is from tumor and nuclear medicine hospital (Al-Hafith Hospital) in Mosul city. The healthy (control) group consisted of (20) healthy females aged (35-68) years.

\section{Samples Collection and Analysis}

Venous blood samples were drawn from each patient then transferred immediately to a clean dry plain tube. After removing the needle, the blood was allowed to clot for at least (10-15) min. at room temperature and then centrifuged for (10) min. at (3500 rpm). Serum was collected to measure some biochemical parameters in the laboratory of Chemistry Department, College of Education.

Methods: Serum vitamin C and vitamin E were measured spectro-photometrically. Vitamin $\mathrm{C}$ was determined by treatment with 2,4 - dinitro phenylhydrazine (DNPH) (Stanley et al., 1979). The method determination of vitamin $E$ in serum is based on the oxidation reduction reaction using Emmerie - Engle Reaction (Varley et al., 1980). 
The level of serum GSH was determined by using modified method described by (Sedlak and Lindsay, 1968) using Ellman's reagent (DTNB)[5,5-dithiobis(2-Nitrobenzoic acid)].

Serum MDA was measured by a modified method described by (Guidet and Shah, 1989) using thiobarbituric acid.

Peroxynitrite $\left(\mathrm{ONOO}^{-}\right)$was measured by the modified method described by (Vanuffelen et al., 1998) based on the ability of peroxynitrite to convert the phenol to nitrophenol which can be estimated spectrophotometrically.

LDH was assayed using fortress kit (United Kingdom), by measuring the rate of absorbance change at $340 \mathrm{~nm}$ due to the reduction (Tietz, 1976).

The levels of serum trace elements $\left(\mathrm{Cu}^{++}\right.$and $\left.\mathrm{Zn}^{++}\right)$were determined using the atomic absorption spectrophotometry (Willard et al., 1974) in the laboratory of Department of Biology, College of Science.

\section{Statistical Analysis}

The data were subjected to a statistical analysis using the student unpaired t- test for comparison of means between patients and controls. All the data were expressed as mean \pm standard deviation (SD) of the mean. P-values $\leq 0.05$ were considered significant (Kirkwood, 1988).

\section{RESULTS}

The results of the measured biochemical parameters are summarized in the table (1). The result showed a significant increase $(p \leq 0.05)$ in the level of MDA, peroxynitrite, LDH and copper in serum of uterine cancer females compared to healthy females. There was a significant decrease $(p \leq 0.05)$ in vitamin $\mathrm{C}$, vitamin $\mathrm{E}$, GSH and zinc levels in serum of females with uterine cancer compared to healthy ones.

Table 1: Values of biochemical parameters in females of uterine cancer and healthy females

\begin{tabular}{|l|c|c|}
\hline \multicolumn{1}{|c|}{$\begin{array}{c}\text { Biochemical } \\
\text { parameters }\end{array}$} & $\begin{array}{c}\text { Healthy females } \\
(\mathbf{n}: \mathbf{2 0})\end{array}$ & $\begin{array}{c}\text { Uterine cancer } \\
\text { females (n:20) }\end{array}$ \\
\cline { 2 - 3 } & Mean $\pm \mathrm{SD}$ & Mean $\pm \mathrm{SD}$ \\
\hline Vitamin $\mathrm{C}(\mu \mathrm{mol} / \mathrm{L})$ & $39.84 \pm 8.53$ & $25.96 \pm 5.68^{*}$ \\
\hline Vitamin $\mathrm{E}(\mu \mathrm{mol} / \mathrm{L})$ & $18.33 \pm 2.22$ & $11.88 \pm 2.65^{*}$ \\
\hline Glutathione $(\mu \mathrm{mol} / \mathrm{L})$ & $12.34 \pm 2.77$ & $8.01 \pm 2.85^{*}$ \\
\hline Malondialdehyde $(\mu \mathrm{mol} / \mathrm{L})$ & $2.30 \pm 0.75$ & $5.64 \pm 1.98^{*}$ \\
\hline Peroxynitrite $(\mu \mathrm{mol} / \mathrm{L})$ & $72.66 \pm 12.05$ & $93.06 \pm 10.07^{*}$ \\
\hline Lactate dehydrogenase $(\mathrm{U} / \mathrm{L})$ & $143.03 \pm 18.69$ & $253.77 \pm 33.76^{*}$ \\
\hline Copper $(\mu \mathrm{mol} / \mathrm{L})$ & $17.56 \pm 2.43$ & $22.09 \pm 2.39^{*}$ \\
\hline Zinc $(\mu \mathrm{mol} / \mathrm{L})$ & $15.58 \pm 2.41$ & $11.05 \pm 1.76^{*}$ \\
\hline
\end{tabular}

*Significant differences at $\mathrm{P} \leq 0.05$ 


\section{Vitamin C:}

\section{DISCUSSION}

The results in Table (1) showed a significant decrease in vitamin $\mathrm{C}$ level in serum of uterine cancer females $(\mathrm{p} \leq 0.05)$ when compared with healthy females. Similar results showed that the vitamin $\mathrm{C}$ concentrations decreased in the serum of patients with cervical cancer (Manju et al., 2002).

The decreased in the vitamin $\mathrm{C}$ levels may be associated with its act as antioxidant where it gets utilized, vitamin $\mathrm{C}$ reduces the tissues damage and removes free radicals, it directly react with $\mathrm{O}_{2}$ and $\mathrm{OH}^{\circ}$ (Koechlin, 1998; Niki, 1991) and reformation of vitamin $\mathrm{E}$ from tocopherol radical which form as a result of lipid peroxidation, so that vitamin $\mathrm{C}$ contributes with vitamin $\mathrm{E}$ in protecting cells from damage (Stahl and Sies, 1997).

\section{Vitamin E:}

Table (1) showed a significant decrease in vitamin E level in serum of uterine cancer females $(p \leq 0.05)$ when compared with healthy females. The obtained results were in agreement with those reported by other (Manju et al., 2002; Bhuvarahamurthy et al., 1996) which showed a decrease in vitamin E level in cervical cancer patients. The reasons for the decreasing of vitamin $\mathrm{E}$ concentrations in uterine cancer patients might be attributed its ability to scavenge lipid peroxides and prevents the cellular damage by the free radicals (Manju et al., 2002). Vitamin $\mathrm{E}$ is the major antioxidant in cell membranes where it protects membrane structures from lipid peroxidation and severe oxidative damage, which tends to be initiated at polyunsaturated fatty acids (Gillham et al., 2000).

The results of several studies suggest that the intake of vitamins, including vitamin $\mathrm{C}$ and vitamin $\mathrm{E}$ from foods or supplements, may be reduce the risk of endometrial cancer (Bandera et al., 2009).

\section{Glutathione:}

The statistical analysis showed that there is a significant decrease in GSH level in serum of uterine cancer females $(p \leq 0.05)$ when compared with the healthy females. This finding is in agreement with those reported by other investigators (Iyoti et al., 2009), which showed that, the level of glutathione is lower in uterine cancer patients. Several studies showed that GSH concentration decreased in cervical, ovarian and colorectal cancer (Iyoti et al., 2009; Skrzydlewska et al., 2005). The reduction in the GSH level may be resulted in increasing the defense against oxidant damage in cancer. GSH can play directly as an antioxidant in many ways as a free radical scavenger or as a co-substrate of some enzymes like glutathione peroxidase, lower levels of glutathione may favor an overproduction of free radicals and lipid peroxides which in turn may induce damage to the DNA and the cell membrane (Iyoti et al., 2009; Suleyman et al., 2003).

\section{Malondialdehyde:}

Table (1) showed that there is a significant increase in MDA concentration in serum of uterine cancer females $(p \leq 0.05)$ when compared with the healthy females. These results were in agreement with other investigations (Pejic et al., 2009; Pejic et al., 2006), which showed an increase in concentration of lipid peroxidation products, as markers of oxidative stress whereas the level of antioxidants decreased in uterine cancer patients. The rise in MDA concentration could be due to increased generation of (ROS) due to the excessive oxidative damage generated in uterine cancer patients, oxygen radical production, which increases with clinical progression of diseases, involves increased lipid peroxidation, as a 
result of which there are cellular membrane degeneration and DNA damage (Pejic et al., 2006).

Finally, the increase in the levels of MDA indicated the upsurged lipid peroxidation as a consequence of the increase in free radical generation, these free radical may cause profound alterations in the function of the cell membrane and also structural organization of DNA leading to mutations, therefore, it can be stated that lipid peroxidation product is one of the possible causes of uterine cancer progression (Wagner et al., 1998).

\section{Peroxynitrite:}

The increase in the levels of the free radicals nitric oxide (NO) and super oxide $\left(\mathrm{O}_{2}{ }^{-}\right)$ produced $\mathrm{ONOO}^{-}$may be occur in malignancies in vivo (Cobbs et al., 2003).

The results in Table (1) showed a significant elevation in peroxynitrite in the serum of uterine cancer females compared with the healthy females. The increase of peroxynitrite might be due to the excess of $\mathrm{O}_{2}{ }^{-}$, which is formed as a result of reaction between $\mathrm{NO}^{\circ}$ and $\mathrm{O}_{2}{ }^{--}$(Cobbs et al., 2003; Paul et al., 1998).

\section{Lactate Dehydrogenase:}

Lactate Dehydrogenase is an enzyme that is found in almost all body tissues, it's one of the enzyme systems preferentially produced and retained by cancer cells, being necessary to maintain tumor growth. LDH is released into the blood stream when cells are damaged or destroyed and the activity of the enzyme will change (Rijke and Trienekens, 1985).

The results in Table (1) showed a significant increase $(\mathrm{p} \leq 0.05)$ in LDH activity in the serum of uterine cancer females compared with the healthy females. The obtained results were in agreement with those reported by other investigators (Subramanian et al., 2009; Kumar et al., 1988), which showed a higher activity of LDH in cervical cancer patients.

On the other hand, Subramanian et al., (2009) recorded changes in the total LDH activity in serum and tissues of cervical carcinoma patients, and they suggested that LDH isoenzyme is a useful biochemical tumor indicator for diagnosis and treatment monitoring of the disease, and to assess the grade of malignancy. The increase of LDH activity may be attributed to the genomic changes during malignant transformation, the main reason for the increase of LDH was due to increased tumor cells also produce more amount of lactic acid, and mainly due to the breakdown of glycoprotein into lactic acid formation (Subramanian et al., 2009).

\section{Copper:}

The level of copper in serum of females with uterine cancer are found to be significantly increased $(\mathrm{p} \leq 0.05)$ when compared with the healthy females as shown in Table (1). A similar result showed that the copper concentration increases in serum of patients with cervical cancer (Naidu et al., 2007). Copper can interact directly with the bases of DNA. The addition of copper to DNA in vitro mediates more extensive DNA base damage inducing more mutations, therefore, the inactivation or loss of certain tumor suppressor genes can lead to initiation and progression of carcinogenesis (Singh et al., 1990).

\section{Zinc:}

The statistical analysis showed a significant decrease $(p \leq 0.05)$ in zinc level in serum of uterine cancer females compared with the healthy females. The obtained results were in agreement with those reported by others (Naidu et al., 2007) which showed that there is lower in zinc levels in cervical cancer patients. 
It was noted by (Al-Taee, 2003) that the zinc concentration in serum of patients with different types of cancer was significantly decreased when compared with control groups. Zinc acts as a cellular growth protector, and it control the membrane integrity and membrane stability. So, it may be happen that the cancer cell may consume the zinc present in the circulation for tumor growth and maintain its membrane integrity (Beerheide et al.,1990). This might be the possible reason for depletion of zinc in uterine cancer patients.

\section{CONCLUSION}

It is concluded that the parameters a raised from the increase in levels of MDA, peroxynitrite, $\mathrm{LDH}$ and copper, and the decrease in the levels of vitamin $\mathrm{C}$, vitamin $\mathrm{E}, \mathrm{GSH}$ and zinc which was noted in uterine cancer, may be used in diagnosis of uterine cancer.

\section{REFERENCES}

Ahmed, M.I.; Fayed, S.T.; Hossein, H.; Tash, F.M. (1999). Lipid peroxidation and antioxidant status in human cervical carcinoma. Dis Markers, 15, 283-291.

Allen, D.; Khaw, P.; Leung, S. (2011). Uterine cancer. Cancer Council Victoria, 61, 426, $486,715$.

Altaee, A. H. (2003). A new relationship between Cytidine deaminase activity and cancer via oxidative hypothesis. M.Sc. Thesis, College of Science, University of Babylon, Iraq.

Bandera, E.V.; Gifkins, D.M.; Moore, D.F.; McCullough, M.L.; Kushi, L.H. (2009). Antioxidant vitamin and the risk of endometrial cancer adose-response metaanalysis. Cancer Causes and Control, 20(5), 699-711.

Beerheide, W.; Bernard, H.; Tan, Y.; Ganesan, A.; Rice, W.; Ting, A. (1990). Potential drugs against cervical cancer. Zinc- ejecting inhibitors of the human papillomavirus Type 16E 6 oncoprotein. J. Formos Med. Assoc. Aug., 8, 677- 82.

Bhuvarahamurthy, V.; Balasubramanian, N.; Govindasamy, S. (1996). Effect of radiotherapy and chemoradiotherapy on circulating antioxidant system of human uterine cervical carcinoma. Molecular and cellular Biochemistry, 158, 17- 23.

Block, G. (1992). Fruit, vegetables and cancer prevention: A review of the epidemiological evidence. Nutr Cancer, 18 (1), 1-29.

Buchanan, E.M.; Weinstein, L.C.; Hillson, C. (2009). Endometrial cancer. Am. Fam. Physician, 80(10), 1075-1080.

Cobbs, C.S.; Whisenhunt, T.R.; Wesemann, D.R.; Harkins, L.E.; Van Meir, E.G.; Samanta, M.(2003). Inactivation of Wild- Type p53 protein function by reactive oxygen and nitrogen species in malignant glioma cells. Can. Res., 63, 8670- 8673.

Gillham, B.; Papachristodoulou, D.K.; Thomas, J.H. (2000). "Will's Biochemical Basis of Medicine". 3rd. ed., Butte Worth- Heineman, Great Britain, pp. 343-352.

Giordano, A.; Bovicelli, A.; Kurman, R.J. (2007). "Molecular Pathology of Gynecologic Cancer". Humana Press Inc., Totowa, New Jersey, pp. 51-53. Endometrial Cancer Part III.

Guidet, B.; Shah, S.V. (1989). Am. J. Physiolo., 257 (26), 440 cited by Muslih, R.K.; AlNimer, M.S.; Al-Zamely, O.M. (2002). The level of Malondialdehyde after activation with $\mathrm{H}_{2} \mathrm{O}_{2}$ and $\mathrm{CuSO}_{4}$ and inhibition by deferoxamine and molsidomine in the serum of patient with acute myocardial infarction. Nat. J. Chem., 5,139-148. 
Iyoti, S.; Neelima, S.; Biharilal, S.S.; Achala, S. (2009). Study of blood levels of antioxidant enzymes and erythrocyte malondialdehyde (MDA) in ovarian, cervical and uterine cancer at stage I. J. Obstet. Gynecol. India, 59(3), 242- 245.

Kang, D.H. (2002). Oxidative stress, DNA damage and breast cancer. AACN Clin. Issues, 13, 540-549.

Kirkwood, B.R. (1988). "Essentials of Medical Statistics". Blackwell Scientific Publications, U.K., pp. 33-41.

Koechlin, A. (1998). Ascorbic acid in the prevention and treatment of cancer. Alternative Medicine Review, 3(3), 174- 86.

Kumar, M.; Birdi, A.; Gupta, Y.N.; Gupta, S. (1988). Serum lactate dehydrogenase isoenzymes alternation in carcinoma cervix uteri. Int. J. Gynaecol. Obset., 27(1), 91- 95.

Manju, V.; Sailaja, J.K.; Nalini, N. (2002). Circulating lipid peroxidation and antioxidant status in cervical cancer patients: acase- control study. Clinical Biochemistry, 35(8), $621-625$.

Mila-Kierzenkowska, C.; Kornelia Kodiziora, K.; Wozniak, A. (2004). The effect of brachytherapy on antioxidant status and lipid peroxidation in patients with cancer of uterine cervix. Cellular and Molecular Biology Letters, 9, 511-18.

Naidu, M.S.; Suryakar, A.N.; Swami, S.C.; Katkam, R.V.; Kumbar, K.M. (2007). Oxidative stress and antioxidant status in cervical cancer patients. Indian J. Clinical Biochemistry, 22(2), 140- 144.

Niki, E. (1991). Action of ascorbic acid as a scavenger of active stable oxygen radical. Am. J. Clin. Nutr., 54(11), 195- 45.

Paul, C.; Ying, L.; Calomme, M.; Pieters, L.; Vlietnick, A.; Bart, V.; Luc, P.; Arnold, J.V.; Vanden, D. (1998). Structure - activity relationship and classification of flavonoids as inhibitors of xanthine oxidase and superoxide scavengers. J. Nat. Prod., 61(1), $71-76$.

Pejic, S.; Kasapovic, J.; Todorovic, A.; Stojiljkovic, V.; Pajovic, S.B. (2006). Lipid peroxidation and antioxidant status in blood of patients with uterine myoma, endometrial polypus, hyperplastic and malignant endometrium. Biological Research, 39(4), 619-629.

Pejic, S.; Todorovic, A.; Stojiljkovic, V.; Kasapovic, J.; Pajovic, S.B. (2009). Antioxidant enzymes and lipid peroxidation in endometrium of patients with polyps, myoma, hyperplasia and adenocarcinoma. Reproductive Biology and Endocrinology, 7, 149.

Rijke, D.; Trienekens, P.H. (1985). Variant expression of lactate dehydrogenase complex, interfering with isoenzyme analysis. Clin. Chem. Acta., 146, 135.

Sedlak, J.; Lindsay, R.H. (1968). Analytical Biochemistry. 192 p. cited by Al-Zamely et al., 2001.

Seyfried, T.N.; Shelton, L.M. (2010). Cancer as a metabolic disease. Seyfried and Shelton Nutrition and Metabolism, 7,7.

Singh, M.; Dwivedi, S.; Singh, G.; Bajpai, M. (1990). Serum copper levels in different stages of carcinoma. Ind. J. Matern Child. Health Mar., 1(1), 12- 4.

Skrzydlewska, E.; Sulkowski, S.; Koda, M.; Zalewski, B.; Kanczyqa- Koda, L.; Sulkowska, M. (2005). Lipid peroxidation and antioxidant status in colorectal cancer. World $J$. Gastroenterol, 11(3), 403- 406. 
Stahl, W.; Sies, H. (1997). Antioxidant defense vitamins E and C and carotnoids. Diabetes, 46, 14- 18.

Stanley, T.; David, T.; Howerds, S. (1979). "Selected Method for the Determination of Ascorbic Acid in Animal Cells, Tissues and Fluids". Method in Enzymology, Acad. Press Inc., N.Y., Vol. 62, pp. 6-9. Vitamins and Coenzymes Part D.

Subramanian, N.; Krishnan, H.M.; Venkatachalam, P.; Kamatchi, P.A.C. (2009). A study of lactate dehydrogenase (LDH) isoenzyme is a biochemical tumor marker in cervical carcinoma patients. Int. J. Hum. Genet, 9(1), 5- 12.

Suleyman, D.; Mustafa, Y.; Mchmet, K.; Natan, A.; Divler, A.; Ahmet, A. (2003). Role of free radicals in peptic ulcer and gastritis. Turk. J. Gastroenterol., 14(1), 39- 43.

Sun, Y. (1990). Free radicals, antioxidant enzymes and carcinogenesis. Free Radic. Bio. Med., 8, 583-99.

Tietz, N.W. (1976). "Fundamentals of Clinical Chemistry". W. B. Saunders Company, Philadelphia.

Vanuffelen, B.E.; Van Derzec, J.; Dekoster, B.M. (1998). Biochem. J., pp.330-719 cited by Al-Zamely, O.M.; Al-Nimer, M.S.; Muslih, R.K. (2001). Detection the level of peroxy nitrite and related with antioxidant status in the serum of patient with acute myocardial infarction. Nat. J. Chem., 4, 625-637.

Varley, H.; Gowenlock, A.H.; Bell, M. (1980). "Practical Clinical Biochemistry". William Heinemann Medical Books LTD, London, Vol.1, pp. 222-225, 553-555.

Wagner, G.; Lubin, Y. (1998). "Oxidative Damage to Red Cells in Cellular Antioxidant Defense Mechanism". CRC Press. Bacon Raton, pp. 333- 335.

Willard, H.H.; Meritt, L.L.; Dean, J.A. (1974). "Instrumental Methods of Analysis". 5th.ed., D. Van Nostrand Company, New York, pp. 350-388. 